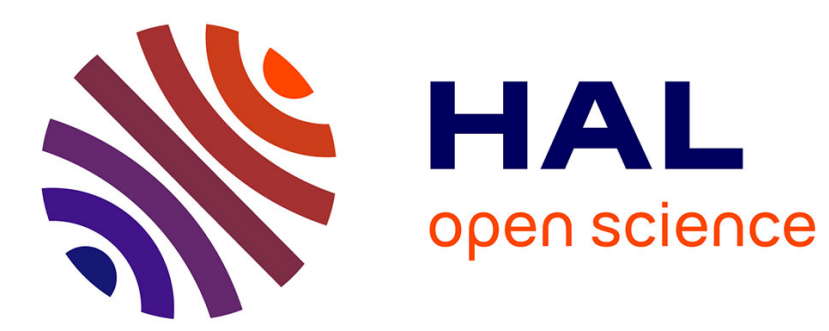

\title{
The Middle Paleolithic of Arabia: The View from the Hadramawt Region, Yemen \\ Rémy Crassard
}

\section{To cite this version:}

Rémy Crassard. The Middle Paleolithic of Arabia: The View from the Hadramawt Region, Yemen. M.D. Petraglia; J.I. Rose. The Evolution of Human Populations in Arabia, Springer, pp.151-168, 2009, Vertebrate Paleobiology and Paleoanthropology, 978-90-481-2718-4. 10.1007/978-90-481-2719-1_12 . hal-01828461

\section{HAL Id: hal-01828461 https://hal.science/hal-01828461}

Submitted on 2 Sep 2018

HAL is a multi-disciplinary open access archive for the deposit and dissemination of scientific research documents, whether they are published or not. The documents may come from teaching and research institutions in France or abroad, or from public or private research centers.
L'archive ouverte pluridisciplinaire HAL, est destinée au dépôt et à la diffusion de documents scientifiques de niveau recherche, publiés ou non, émanant des établissements d'enseignement et de recherche français ou étrangers, des laboratoires publics ou privés. 
The Evolution of Human Populations in Arabia Paleoenvironments, Prehistory and Genetics

Michael D. Petraglia

Jeffrey I. Rose

Editors

Springer 


\title{
Chapter 12 \\ The Middle Paleolithic of Arabia: The View from the Hadramawt Region, Yemen
}

\author{
Rémy Crassard
}

Keywords Dispersals - Hadramawt - Levallois - Middle Paleolithic • Yemen

\section{Arabia: A New “El Dorado" for Evolutionary Scholars?}

While prehistoric research in the Arabian peninsula is still in its primary stages of development, the very existence of this book is proof of a recent growing interest in the region. Yet, the interest in the prehistory of the region is outshined by the dearth and frailty of the available data. We must then ask ourselves, why such interest and enthusiasm? And is it really justified to theorize about the contribution of Arabia for human prehistory if the data remain scant? It can certainly be explained, as Petraglia (2007: 383) correctly states, by the progressive reorientation of research towards areas of the world where it is more "logical" to look in order to understand "the evolutionary history of geographically widespread populations". Consequently, this phenomenon is akin to a revolution in the small world of Arabian prehistoric research; a revolution that carries great aspirations for crucial questions such as the origin of the dispersion of anatomically modern humans out of Africa. While the data are scarce, the passion which one can have for the prehistory of a region such as Arabia is fully justified by the simple recognition of its being an area laden with enormous possibility.

Given the possibilities offered by this vast peninsula, what data can we rely on? There have been archaeological surveys carried out in Arabia for more than half a century. These surveys have shed light on the existence of an Arabian Paleolithic. Nonetheless, the presence of a Paleolithic in Arabia became problematic as it became necessary to find points of comparisons with well-established, or at least, better established, neighboring industries, such as those of East Africa and

R. Crassard $(\bowtie)$

Leverhulme Centre for Human Evolutionary Studies, University of Cambridge, The Henry Wellcome Building,

Fitzwilliam Street, Cambridge, CB2 1QH, UK

e-mail: rc461@cam.ac.uk the Levant. The chrono-cultural framework was thus gradually modeled after the great phases of the Lower and Middle Paleolithic: Oldowan, Acheulean, and Mousterian or Middle Stone Age. All discoveries made in Arabia were adapted to this framework and not vice versa; simply put, the Arabian framework was not made by regional discoveries. This very fact is of great importance, as no site has ever been properly chronometrically dated to the Paleolithic period. Any pebble-tool was thus Oldowan, any biface was associated to the Acheulean, and any Levallois core to the Mousterian. All of these labels happen to be associated with dates that are in many cases of a low degree of accuracy which renders such designations highly debatable at the very least, especially in light of the fact that these sites are dated typologically and not absolutely. It appears then, that the lithic industries are the best available data to study, waiting for some better dated and archaeologically richer contexts.

\section{The Arabian Middle Paleolithic Background}

Questions concerning affinities between Arabia and its betterdocumented neighboring regions, such as the Levant and East Africa, during the Middle Paleolithic have long been the subject of debate. However, the Middle Paleolithic of Arabia suffers from numerous lacunae. From a paleoanthropological point of view, no hominin fossils have been discovered thus far. In addition, all of the artifacts which presume a Paleolithic age were collected from the surface of sites, which are undated. All that remains are human expansion or demographic models based on genetic data. Given the current state of the research which mainly relies on models and undated in situ artifacts, it is safe to say that the existence of an Arabian Middle Paleolithic that is more or less contemporary with geographically close and well-identified cultural complexes elsewhere, would present an occasion to consider and discuss such networks of diffusion and dispersal.

In Europe, the Levant and Africa, the Middle Paleolithic is generally characterized by Levallois debitage, which more or less comes to fruition in the Upper Acheulean period, and 
develops widely thereafter. A mental conceptualization that can be clearly seen with the Levallois concept, consequently dominates lithic production. This conceptualization is illustrated by a predetermination of the debitage products, which are obtained from more or less variable Levallois methods of debitage (Boëda, 1994). As the Levallois debitage is present in various regions of the world, the analyses based on this classificatory unit are then of significant value for making comparisons.

The presence of Levallois debitage in Arabia was identified rather early by the first pioneers of Yemeni archaeology. Caton-Thompson $(1938,1953)$ was the first archaeologist to have detected a potential Pleistocene human presence in Hadramawt. Her work was followed by Van Beek et al. (1963), Inizan and Ortlieb (1987), Inizan (1989), Amirkhanov (1991, 1994a) and Zimmerman (2000), to quote only the principal archaeologists. However, of the sites that produced a Levallois industry in the whole of the Arabian peninsula, not a single one was able to provide either intact stratigraphy or relative or absolute dates. A cumulative review of the state of Paleolithic research in Arabia was, nonetheless, carried out by Petraglia and Alsharekh (2003), and one, earlier, by Zarins (1998).

\section{Levallois Industries and the Middle Paleolithic: How and Why Study Surface Material in Yemen?}

\section{Universal Dating of Sites with Levallois Technology?}

Until very recently, not a single stratified site in Arabia had produced sufficient indications of a Levallois debitage for such a method to have been associated with a precise date or period. Despite the large numbers of Levallois artifacts collected from the surface of sites, and particularly on the plateaus of Hadramawt in Eastern Yemen, the poor contexts and lack of dated comparisons rendered them chronologically unidentifiable. Having said this, what dates can one allot temporarily to the use of the Levallois concept in Yemen?

Levallois debitage was in use for more than 400 thousand years. It appears from the Acheulean period in Africa and is attested in Western Europe from the end of the isotopic stage 10 alongside Middle Acheulean type assemblages and in particular in the Somme basin (Tuffreau, 2004: 81-82) of northern France (ca. 600-400 ka). It spreads throughout Eurasia in the Middle Paleolithic (from $300 \mathrm{ka}$ ) during the Mousterian period (300-30 ka), starting at isotopic stage 8 . The presence of a Levallois technology is therefore quite ancient throughout Africa, the Near-East, Europe and Asia.

Nevertheless, the typical attribution of the use of the Levallois concept to periods of the Middle Paleolithic can be misplaced as this debitage modality has been proven to be present in more recent lithic sets throughout the world. It is for such reasons that the use of an old system of dating the Levallois technology in Yemen, especially in the absence of reliable relative or absolute dates held such reservations. Nonetheless the data presented hereafter lead us to allot a Pleistocene date to the Levallois methods from the Hadramawt area.

\section{Some Elements Largely in Favor of Pleistocene Dating}

The Arabian peninsula is located at the crossing between Africa, the Levant and Asia. It would thus seem, on the basis of a diffusionist theorization, that Arabia was in one way or another, in contact with populations that used this type of debitage. Even if one considers the possibility of a late contact with African MSA traditions or Levantine Middle Paleolithic ones, it still would have happened during the Pleistocene. Moreover, paleoenvironmental and geological data indicate periods when the sea level was very low and crossing the Red Sea would have been feasible. Other paleoclimatic data indicate periods during which aridity was less extreme and the peopling of Arabia would have been facilitated. These above-mentioned periods occur during the Pleistocene (Burns et al., 2003).

Patina as a relative dating method is fundamentally more important on Levallois pieces. Comparison of the patina acquired on Levallois pieces as opposed to typical Early Holocene artifacts systematically produced the same result. Although a comparison of the degree of patina is an unreliable method that the author partly denounced in a previous study (Crassard, 2007: 71-73), not a single non-heavily patinated Levallois element has ever been collected from a surface site. This is absolutely not the case for Holocene industries, which can be patinated, but are not in the majority of instances.

Finally, stratified Holocene assemblages have never provided components of a Levallois debitage. We can thus relatively date Levallois industries to a period of time preceding the typical Holocene industries found in Hadramawt (Crassard et al., 2006: 169; Crassard, 2007: 251-252).

Consequently, without more precision, the Levallois industries from Yemen favor a Pleistocene period date. What then is the significance of using a technological approach (study of techniques) for such imprecisely dated data?

Lithic industries can deliver technical, cultural and at times chronological information, but their study cannot be an end in and of itself. The numerous surface sites in Arabia cannot be dated precisely. However, the lithic evidence is impressive due to the enormous quantity of surface finds. From this point of view, the study of lithic technology constitutes a relevant tool to distinguish convergences, diffusions and autonomous inventions. While the technological approach alone is not sufficient, it is a important heuristic tool. 
Fig. 1 The Arabian peninsula and Yemen location

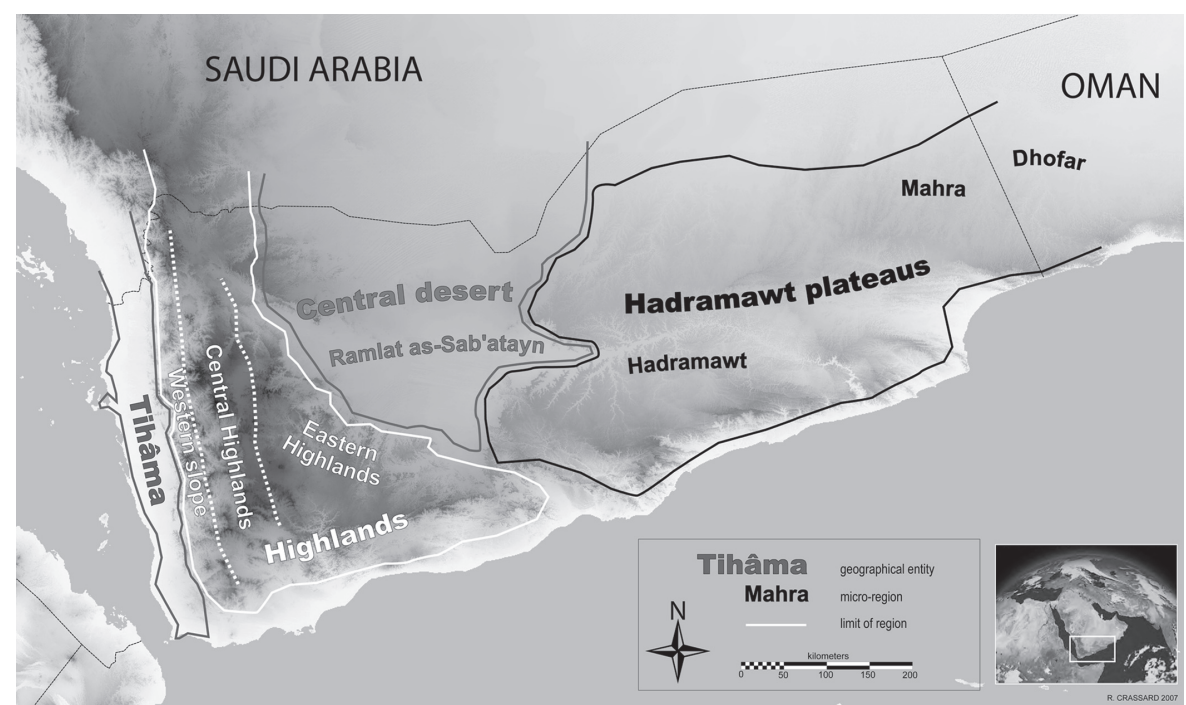

\section{Levallois Assemblages from Hadramawt: The Contexts}

\section{The Hadramawt Region}

In Southern Arabia (Fig. 1), the Aden Gulf rift opened approximately 34 million years ago during the Early Oligocene. This fissure was created earlier than the rifting of the Red Sea, and was accompanied by the rising of the Hadramawt (Eastern Yemen) and Dhofar plateaus (Western Oman; Sanlaville, 2000: Fig. 2). The Paleocene and Eocene limestone Hadramawt plateau (locally called Jawl meaning "plateau") reaches a maximum height of more than 1,000 m.

A vast network of abrupt valleys, which are often canyons, leads rainwater towards the Wâdî Hadramawt. This wadi consists of a gigantic gorge that crosses most of eastern Yemen (from west to east). The eastern half bears the name of Wâdî Masîla, until it reaches its delta near the Arabian Sea. Collapsing cones were formed by erosional processes at the base of the high limestone cliffs and in some cases provide access to the top of the plateaus. East of the Hadramawt plateaus is the modern Yemeni province of Mahra. In this region the geological limestone formations gradually descend to the limestone hills of Dhofar in Western Oman.

\section{The Context of the Discoveries}

A significant number of lithic industries from all periods of prehistory were recently collected as part of two archaeological research projects in Hadramawt (Fig. 2): The Roots of Agriculture in Southern Arabia Project (RASA) and the French Archaeological Mission in Jawf-Hadramawt (HDOR).

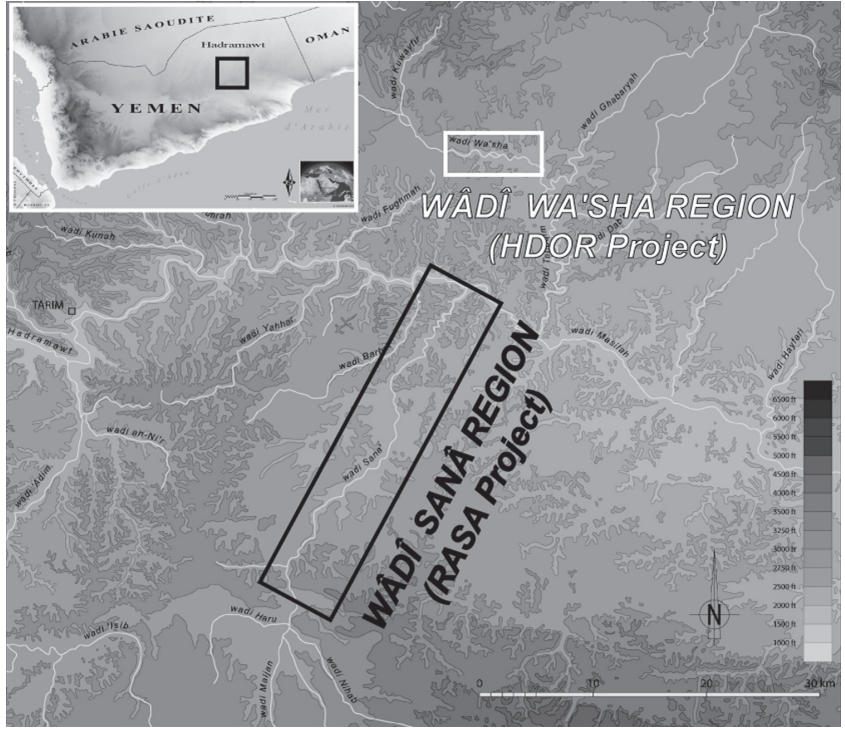

Fig. 2 The Hadramawt region and the project locations

The HDOR and RASA fieldwork projects produced 48 surface sites ( 21 for HDOR and 27 for RASA) that delivered characteristic Levallois elements (Tables 1 and 2). In most of these cases, the presence of this lithic type was discrete forming part of moderate surface assemblages, except some rare cases where remains of debitage clusters were still visible (remains of workshops). The state of preservation of the lithics collected ranged from average (heterogeneous assemblages, good readability of the scars) to very bad (heterogeneous assemblages, rare artifacts, very eroded and strong patina). Most of the samples collected were heavily patinated or eroded. Only a few sites were characterized by less patinated flint industries, on which knapping stigmata was clearly readable. A selective collecting strategy, which 
Table 1 Levallois cores from HDOR and RASA projects, classified by sites

\begin{tabular}{|c|c|c|c|c|c|c|c|c|c|c|c|c|c|c|c|c|}
\hline \multirow[b]{2}{*}{ Sites } & \multirow[b]{2}{*}{ Core \# } & \multicolumn{3}{|c|}{ Dimensions (in mm) } & \multicolumn{2}{|c|}{ Morphology of final flake } & \multicolumn{10}{|c|}{$\underline{\text { Debitage modalities }}$} \\
\hline & & Length & Width & Thickness & Quadrangular/oval & Triangular & A1 & $\mathrm{A} 2$ & A3 & $\mathrm{B} 1$ & $\mathrm{~B} 2$ & B3 & $\mathrm{B} 4$ & $\mathrm{C}$ & Abandoned & Non-Levallois \\
\hline \multirow[t]{5}{*}{ HDOR 412} & 1 & 63 & 63 & - & $\mathrm{X} ?$ & & $\mathrm{X}$ & & & & & & & & & \\
\hline & 2 & 69 & 54 & - & $\mathrm{X} ?$ & & & $\mathrm{X}$ & & & & & & & & \\
\hline & 3 & 50 & 42 & - & & $\mathrm{X}$ & & & & $\mathrm{X}$ & & & & & & \\
\hline & 4 & 66 & 54 & - & $\mathrm{X}$ & & & & & $\mathrm{X}$ & & & & & & \\
\hline & 5 & 60 & 58 & - & $\mathrm{X} ?$ & & & & & & & & & & $\mathrm{X}$ & \\
\hline \multirow[t]{2}{*}{ HDOR 417} & 1 & 82 & 67 & - & $\mathrm{X} ?$ & & & & $\mathrm{X}$ & & & & & & & \\
\hline & 2 & 84 & 66 & - & $\mathrm{X} ?$ & & & & & & & & & $X$ & & \\
\hline \multirow[t]{2}{*}{ HDOR 526} & 1 & 45 & 41 & 17 & $\mathrm{X} ?$ & & $X$ & & & & & & & & & \\
\hline & 2 & 49 & 44 & 23 & & $X$ & & & & & & & $X$ & & & \\
\hline \multirow{3}{*}{$\begin{array}{c}\text { RASA } 2004 \\
84-0\end{array}$} & 1 & 72 & 60 & - & - & - & & & & & & & & & & $\mathrm{X}$ \\
\hline & 2 & 53 & 51 & - & & $X$ & & & & & $X$ & & & & & \\
\hline & 3 & 55 & 51 & - & $\mathrm{X} ?$ & & & $X$ & & & & & & & & \\
\hline \multirow{3}{*}{$\begin{array}{c}\text { RASA } 2004 \\
84-2\end{array}$} & 1 & 51 & 42 & 20 & & $X$ & & & & & $X$ & & & & & \\
\hline & 2 & 56 & 61 & - & $\mathrm{X} ?$ & & & $X$ & & & & & & & & \\
\hline & 3 & 57 & 47 & - & $\mathrm{X} ?$ & & & & $X$ & & & & & & & \\
\hline \multirow{7}{*}{$\begin{array}{c}\text { RASA } 2004 \\
124-1\end{array}$} & 1 & 72 & 82 & 23 & & $X$ & & & & & & $\mathrm{X}$ & & & & \\
\hline & 2 & 75 & 82 & 27 & $\mathrm{X} ?$ & & $X$ & & & & & & & & & \\
\hline & 3 & 79 & 71 & 37 & & $X$ & & & & & $X$ & & & & & \\
\hline & 4 & 80 & 59 & 35 & & $X$ & & & & & $X$ & & & & & \\
\hline & 5 & 58 & 64 & 39 & $\mathrm{X} ?$ & & & $X$ & & & & & & & & \\
\hline & 6 & 74 & 39 & 30 & & $X$ & & & & & $X$ & & & & & \\
\hline & 7 & 91 & 78 & 50 & & $X$ & & & & $X$ & & & & & & \\
\hline \multirow{4}{*}{$\begin{array}{c}\text { RASA } 2004 \\
149-1\end{array}$} & 1 & 63 & 54 & 17 & $\mathrm{X} ?$ & & $X$ & & & & & & & & & \\
\hline & 2 & 54 & 57 & 12 & & $X$ & & & & & & & $X$ & & & \\
\hline & 3 & 44 & 33 & 25 & & $\mathrm{X}$ & & & & $\mathrm{X}$ & & & & & & \\
\hline & 4 & 45 & 35 & 26 & & $X$ & & & & $X$ & & & & & & \\
\hline \multirow{8}{*}{$\begin{array}{c}\text { RASA } 2004 \\
149-2\end{array}$} & 1 & 59 & 52 & 20 & & $X$ & & & & & & $\mathrm{X}$ & & & & \\
\hline & 2 & 60 & 42 & 22 & & $X$ & & & & & & & $X$ & & & \\
\hline & 3 & 62 & 57 & 25 & $\mathrm{X} ?$ & & $X$ & & & & & & & & & \\
\hline & 4 & 54 & 41 & 18 & & $X$ & & & & & & & $X$ & & & \\
\hline & 5 & 43 & 48 & 21 & $\mathrm{X} ?$ & & $X$ & & & & & & & & & \\
\hline & 6 & 62 & 43 & 25 & & $X$ & & & & & & & & & $\mathrm{X}$ & \\
\hline & 7 & 60 & 48 & 28 & $\mathrm{X} ?$ & & & & & X & & & & & & \\
\hline & 8 & 52 & 45 & 19 & - & - & & & & & & & & & & $\mathrm{X}$ \\
\hline \multirow{2}{*}{$\begin{array}{c}\text { RASA } 2004 \\
153-1\end{array}$} & 1 & 60 & 46 & 18 & & $\mathrm{X}$ & & & & & $X$ & & & & & \\
\hline & 2 & 69 & 52 & 20 & $\mathrm{X}$ & & & & & & & & & & $\mathrm{X}$ & \\
\hline RASA 2004 & 1 & 66 & 38 & 22 & & $\mathrm{X}$ & & & & & & & & & $\mathrm{X}$ & \\
\hline 165-1 & 2 & 50 & 42 & 23 & - & - & & & & & & & & & & $\mathrm{X}$ \\
\hline RASA 2004 & 1 & 55 & 46 & 13 & & $X$ & & & & & $\mathrm{X}$ & & & & & \\
\hline 166-1 & 2 & 47 & 43 & 11 & $\mathrm{X} ?$ & & $X$ & & & & & & & & & \\
\hline & 3 & 62 & 53 & 23 & & $\mathrm{X} ?$ & & & & & $\mathrm{X}$ & & & & & \\
\hline & 4 & 77 & 38 & 23 & & $\mathrm{X} ?$ & & & & & & & $\mathrm{X}$ & & & \\
\hline HDOR 500 & 1 & 69 & 44 & 24 & & $\mathrm{X}$ ? & & & & & & $\mathrm{X}$ & & & & \\
\hline HDOR 520 & 1 & 58 & 44 & 16 & & $\mathrm{X}$ & & & & & & & $\mathrm{X}$ & & & \\
\hline HDOR 527 & 1 & 54 & 53 & 25 & & $\mathrm{X}$ & & & & & & & $\mathrm{X}$ & & & \\
\hline HDOR 566 & 1 & 98 & 90 & 50 & & $\mathrm{X}$ & & & & & & $\mathrm{X}$ & & & & \\
\hline HDOR 571 & 1 & 57 & 31 & 14 & & $\mathrm{X}$ & & & & & & $\mathrm{X}$ & & & & \\
\hline HDOR 574 & 1 & 78 & 62 & 24 & & $\mathrm{X} ?$ & & & & & & $\mathrm{X}$ & & & & \\
\hline $\begin{array}{c}\text { RASA } 2004 \\
135-1\end{array}$ & 1 & 68 & 55 & 14 & & $X$ & & & & & & $\mathrm{X}$ & & & & \\
\hline $\begin{array}{c}\text { RASA } 2004 \\
136-1\end{array}$ & 1 & 84 & 59 & 43 & & $X$ & & & & & $\mathrm{X}$ & & & & & \\
\hline $\begin{array}{c}\text { RASA } 2004 \\
141-1\end{array}$ & 1 & 73 & 65 & 29 & $\mathrm{X} ?$ & & & & & & & & & $X$ & & \\
\hline $\begin{array}{c}\text { RASA } 2004 \\
168-1\end{array}$ & 1 & 65 & 33 & 24 & & $\mathrm{X}$ & & & & & & $\mathrm{X}$ & & & & \\
\hline
\end{tabular}


Table 2 Synthesis of Levallois cores analysis, classified by schemes

\begin{tabular}{|c|c|c|c|c|}
\hline Sites & Core \# & Preparation phase & Production phase & Scheme \\
\hline HDOR 412 & 1 & Centripetal & Unique preferential flake debitage & A1 \\
\hline HDOR 526 & 1 & Centripetal & Unique preferential flake debitage & \\
\hline RASA 2004-124-1 & 2 & Centripetal & Unique preferential flake debitage & \\
\hline RASA 2004-149-1 & 1 & Centripetal & Unique preferential flake debitage & \\
\hline RASA 2004-149-2 & 3 & Centripetal & Unique preferential flake debitage & \\
\hline RASA 2004-149-2 & 5 & Centripetal & Unique preferential flake debitage & \\
\hline RASA 2004-166-1 & 2 & Centripetal & Unique preferential flake debitage & \\
\hline HDOR 412 & 2 & Centripetal & Recurrent preferential flakes debitage & $\mathrm{A} 2$ \\
\hline RASA 2004-84-2 & 2 & Centripetal & Recurrent preferential flakes debitage & \\
\hline RASA 2004-124-1 & 5 & Centripetal & Recurrent preferential flakes debitage & \\
\hline HDOR 417 & 1 & Opposed lateral & Unique preferential flake debitage & A3 \\
\hline RASA 2004-84-0 & 3 & Opposed lateral & Unique preferential flake debitage & \\
\hline RASA 2004-84-2 & 3 & Opposed lateral & Unique preferential flake debitage & \\
\hline HDOR 412 & 3 & Convergent unipolar & "Classical" Levallois point debitage & B1 \\
\hline HDOR 412 & 4 & Convergent unipolar & "Classical" Levallois point debitage & \\
\hline RASA 2004-124-1 & 7 & Convergent unipolar & "Classical" Levallois point debitage & \\
\hline RASA 2004-149-1 & 3 & Convergent unipolar & "Classical" Levallois point debitage & \\
\hline RASA 2004-149-1 & 4 & Convergent unipolar & "Classical" Levallois point debitage & \\
\hline RASA 2004-149-2 & 7 & Convergent unipolar & Recurrent "classical" Levallois points debitage & \\
\hline RASA 2004-84-0 & 2 & Convergent unipolar and lateral & "Constructed" point debitage & B2 \\
\hline RASA 2004-84-2 & 1 & Convergent unipolar and distal & "Constructed" point debitage & \\
\hline RASA 2004-124-1 & 3 & Convergent unipolar and distal & "Constructed" point debitage & \\
\hline RASA 2004-124-1 & 4 & Convergent unipolar and distal & "Constructed" point debitage & \\
\hline RASA 2004-124-1 & 6 & Convergent unipolar and distal & "Constructed" point debitage & \\
\hline RASA 2004-136-1 & 1 & Convergent unipolar and lateral-distal (?) & "Constructed" point debitage & \\
\hline RASA 2004-153-1 & 1 & Distal convergent & "Constructed" point debitage & \\
\hline RASA 2004-166-1 & 1 & Convergent unipolar and distal & "Constructed" point debitage & \\
\hline RASA 2004-166-1 & 3 & Convergent unipolar and distal & "Constructed" point debitage & \\
\hline HDOR 500 & 1 & Bipolar and lateral-distal & "Constructed" point debitage & B3 \\
\hline HDOR 566 & 1 & Bipolar and lateral-proximal & "Constructed" point debitage & \\
\hline HDOR 571 & 1 & Bipolar & "Constructed" point debitage & \\
\hline HDOR 574 & 1 & Bipolar and lateral-distal & "Constructed" point debitage & \\
\hline RASA 2004-124-1 & 1 & Bipolar and lateral & "Constructed" point debitage & \\
\hline RASA 2004-135-1 & 1 & Bipolar and lateral-proximal & "Constructed" point debitage & \\
\hline RASA 2004-149-2 & 1 & Bipolar & "Constructed" point debitage & \\
\hline RASA 2004-168-1 & 1 & Bipolar & "Constructed" point debitage & \\
\hline RASA 2004-149-1 & 2 & Proximal-lateral and opposed lateral & "Constructed" point debitage & B4 \\
\hline HDOR 520 & 1 & Proximal-lateral and opposed lateral & "Constructed" point debitage & \\
\hline HDOR 526 & 2 & Proximal-lateral and opposed lateral & "Constructed" point debitage & \\
\hline HDOR 527 & 1 & Proximal-lateral and opposed lateral & "Constructed" point debitage & \\
\hline RASA 2004-149-2 & 2 & Proximal-lateral and opposed lateral & "Constructed" point debitage & \\
\hline RASA 2004-149-2 & 4 & Proximal-lateral and opposed lateral & "Constructed" point debitage & \\
\hline RASA 2004-166-1 & 4 & Proximal-lateral and lateral & "Constructed" point debitage & \\
\hline HDOR 417 & 2 & Centripetal & Recurrent centripetal debitage & $\mathrm{C}$ \\
\hline RASA 2004-141-1 & 1 & Centripetal & Recurrent centripetal debitage (?) & $\mathrm{C}$ \\
\hline HDOR 412 & 5 & Bipolar & Undetermined (abandoned) & Undet. \\
\hline RASA 2004-149-2 & 6 & Proximal-lateral and distal & Undetermined (abandoned) & Undet. \\
\hline RASA 2004-153-1 & 2 & Parallel unipolar and distal & Levallois debitage? (abandoned) & Undet. \\
\hline RASA 2004-165-1 & 1 & Proximal-lateral and opposed lateral & B4 Levallois debitage? (abandoned) & Undet. \\
\hline
\end{tabular}

consisted mainly of cores, was carried out for the majority of Levallois sites. These cores were later analyzed systematically and provided a significant study of the technical schemes utilized in the final debitage phases in the Hadramawt region. Nevertheless, it is important to keep in mind that the information obtained from these cores is incomplete as only the last stage of debitage is represented.
The majority of the elements that have led to a better comprehension of Levallois variability in South Arabia were discovered in the Wâdî Wa'shah and Wâdî Sanâ, tributaries of the Wadi Hadramawt. To avoid redundancy, the detailed characteristics of these sites will not be described here. It suffices to say that the majority of these sites consist of surface scatters located on the plateau tops. By contrast, the location 
of Holocene sites in the region suggests settlement variability (Crassard, 2007: 154-170, 348-354).

\section{Technological Analysis and Terminology}

The lithic material that originates from the Hadramawt surveys was analyzed on the basis of a grid established by E. Boëda (1994: 22, 35-39), which deals with the characteristics of predetermined removals. Such a process allows for the identification of technical schemes, also called methods, and which are equivalent to the knapper's Levallois conceptualization.

The preferential cores are grouped under several types of preferential removals (quadrangular, oval or trapezoidal flake and Levallois point), whereas the recurrent cores are sorted by modes of manipulation of the debitage surface: unipolar (parallel), bipolar, centripetal (Boëda, 1994: 257258). This technological (study of techniques) approach aims to gain insight into the technical cultural tradition. Such insight can only be attained through a gradual deciphering of the technologies used and through an understanding of the constraints applied to the technical norm of a group (see Boëda, 1994: 263).

\section{Technological Analysis of Levallois Cores}

The technological analysis concerned 56 cores in total (15 for HDOR and 41 for RASA). A total of 10 cores was found isolated, whereas 46 came from 11 "homogeneous" assemblages. These assemblages are mainly made up of cores, as well as some products that resulted from a Levallois debitage modality. These assemblages originate from surface sites in the Hadramawt. The following analysis of these Levallois cores (final stages of debitage) focuses on the variability of the technical schemes involved in the knapping process.

\section{Levallois Assemblages from Hadramawt: The Data}

\section{The First Synthesis on the Levallois Debitage of Hadramawt: Two Methods, Three Groups and Eight Modalities}

Through the study of the methods of debitage made on Levallois cores from the HDOR and RASA project sites, it was possible to isolate three different groups (A, B and C): Group A: Levallois debitage of one (sometimes two) oval, quadrangular or trapezoidal preferential flake(s)
Group B: Levallois point debitage

Group C: centripetal recurrent Levallois debitage

These three groups represent the technical schemes that allowed for a predetermined product to be obtained. A total of eight technical schemes, or debitage modalities, were identified (A1, A2, A3, B1, B2, B3, B4 and C). They reveal technical variability within groups $\mathrm{A}$ and $\mathrm{B}$. A thorough statistical analysis was not undertaken as the cores do not originate from "closed" archaeological contexts.

Through the analysis of the final debitage phases of the cores from Hadramawt, two objectives can be distinguished:

A quantitative objective:

One (even two) products per flaking surface (preferential product Levallois debitage)

Several products per flaking surface (recurrent Levallois debitage)

A qualitative objective:

Debitage of Levallois flakes or points

In the case of the Hadramawt cores, these two abovementioned objectives (quantitative and qualitative) help us to isolate two methods of Levallois debitage (preferential product or centripetal recurrent) which are associated with eight different modalities: A1 to A3, $\mathrm{B} 1$ to $\mathrm{B} 4$ and $\mathrm{C}$.

\section{Group A}

Group A is characterized by:

A debitage of preferential flakes with centripetal preparation (schemes A1 and A2)

A debitage of preferential flakes with "crossed" preparation (scheme A3)

\section{Scheme A1}

Scheme A1 (Fig. 3) is characterized by a Levallois debitage of a unique preferential flake with centripetal preparation. This scheme leads to the obtainment of a preferential flake by shaping the debitage surface centripetally. This particular scheme is represented by seven cores, including three from the same site (RASA 2004149-1, cores 1, 3 and 5).

\section{Scheme A2}

Scheme A2 (Fig. 4) is characterized by a Levallois debitage of recurrent preferential flakes with centripetal preparation. This scheme is represented by four cores collected from four different sites. It is similar to the A1 scheme. However, a second removal is often intended after the first predeter- 
Fig. 3 An example of one core showing Scheme A1 (lithic drawing J. Espagne)
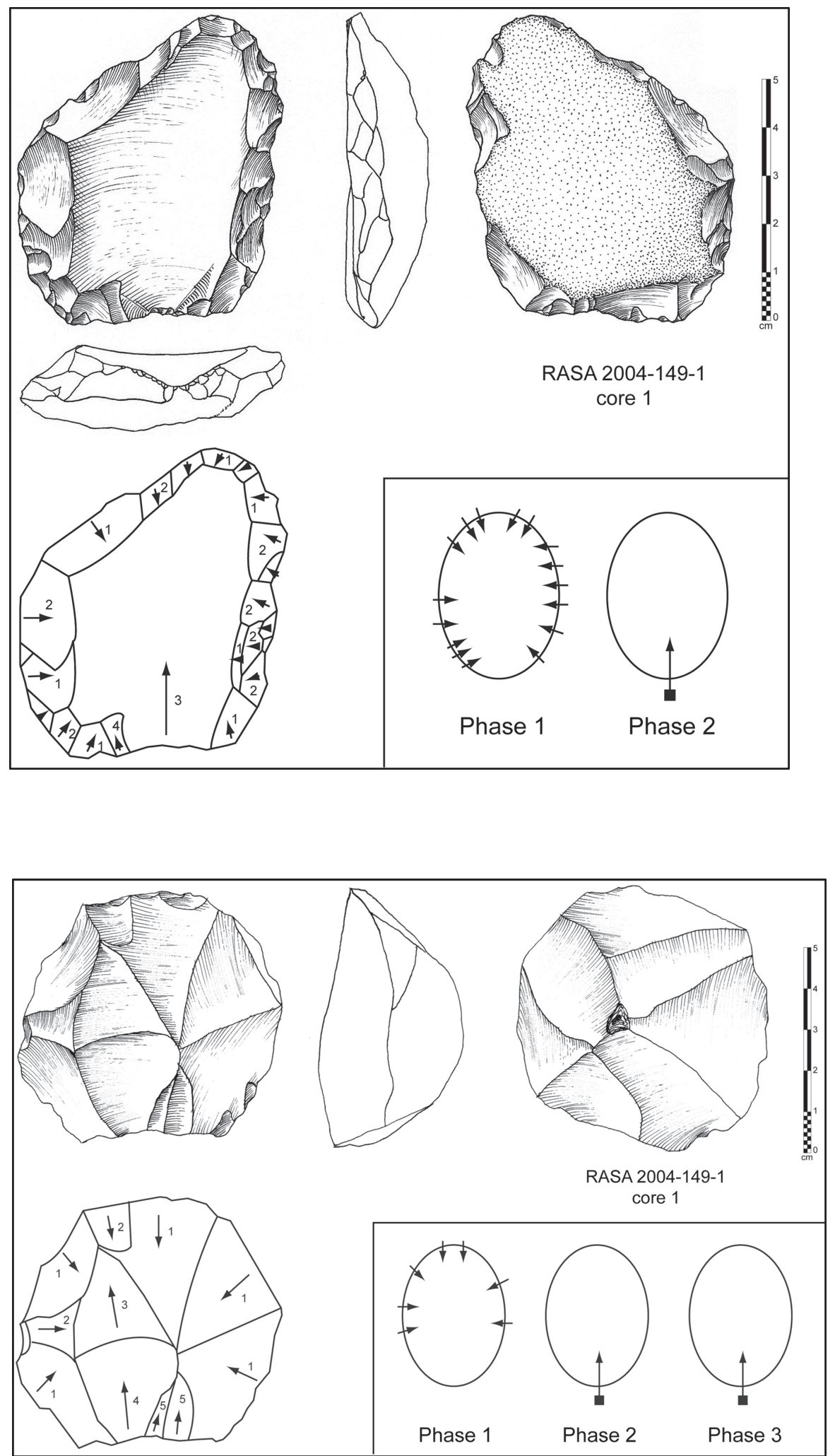

Fig. 4 An example of one core showing Scheme A2 (lithic drawing R. Crassard) arris. In fact, this scheme never follows a lateral arris from the negative of the first predetermined removal. One can see there the search for a second removal which seeks to extend in parallel of the first. It can also be interpreted as a resharpening mined removal. The second removal is knapped from the same debitage axis (proximal part of the core). The second "predetermined" removal occurs at stage 3 of the debitage. This occurs without new convex preparation or new Levallois 
removal. Consequently these pieces could be cores abandoned during unfinished debitage operations. Scheme A2 remains debatable.

\section{Scheme A3}

Scheme A3 is characterized by a Levallois debitage of unique preferential flake with opposed lateral preparation. This scheme is represented by two cores from two different sites. Scheme A3 is similar to scheme A1, except that the preparation of the lateral convexities from the sides of the cores, is carried out in an opposed way. This type of "crossed" preparation suggests a (voluntary?) intention to produce short and a priori wide Levallois flakes. The abandonment of unfinished debitage cores will be considered in the final interpretation of this scheme.

\section{Group B}

Group B is characterized by:

A debitage of preferential triangular flakes with convergent unipolar preparation (scheme B1)
A debitage of preferential triangular flakes with "crossed" preparation (unipolar+lateral, or bipolar+ lateral) (schemes $\mathrm{B} 2, \mathrm{~B} 3$ and B4)

\section{Scheme B1}

Scheme B1 (Fig. 5) is characterized by a Levallois debitage of preferential triangular flakes with convergent unipolar preparation (called "classical" Levallois point production). This scheme concerns six cores, of which two originate from the same site (RASA 2004-149-1, core 3 and 4). This type of method is described by Boëda as the only method (described as "type 3") along with two others (described as "type 7" or "type 3+7"), that characterize a Levallois point core (Boëda, 1994: 86). According to this remark, we will label the cores which present a B1 scheme "classical Levallois point cores", in contrast to schemes B2, B3 and B4 cores which have the same type of predetermined product, but acquired through distinct means.

\section{Scheme B2}

Scheme B2 (Fig. 6) is characterized by a Levallois debitage of preferential triangular flakes with convergent unidirec-
Fig. 5 An example of one core showing Scheme B1 (lithic drawing R. Crassard)

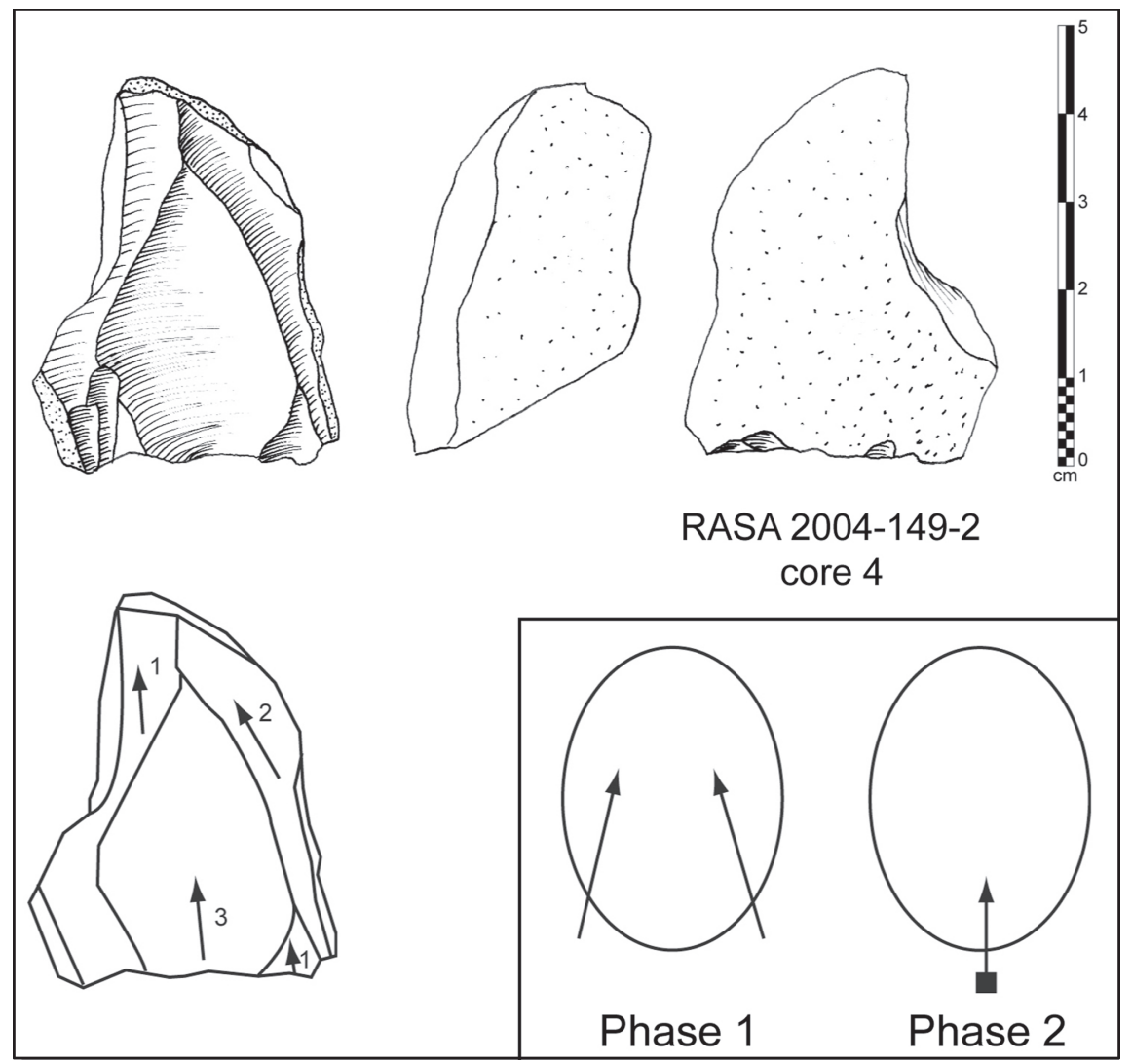


Fig. 6 An example of one core showing Scheme B2 (lithic drawing R. Crassard)

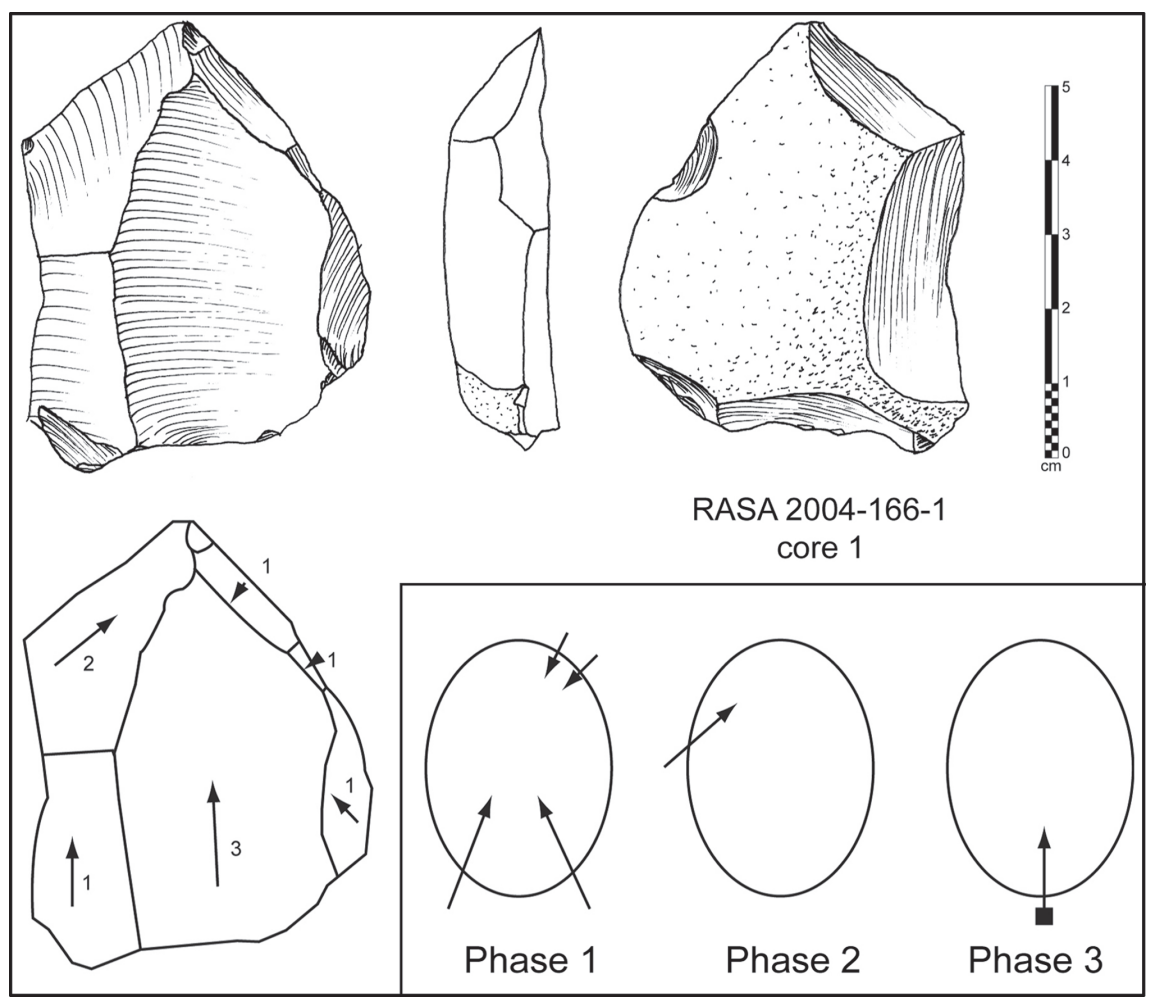

tional preparation and lateral or distal convex reinstallation (called "constructed" Levallois point production). This scheme concerns nine cores, including three from the same site (RASA 2004-124-1, cores 3, 4 and 6), and two others from site (RASA 2004-166-1, cores 1 and 3).Scheme B2 resembles $\mathrm{B} 1$ one but can be differentiated by the production of lateral and/or distal convexity by complementary removals to the typical convergent removals of the B1 scheme. Such a scheme can be interpreted in two ways. The first interpretation of the method is systematic and aims to deliberately acquire a "constructed" Levallois point (This term is taken from E. Boëda who uses it for industries description from layer VI3 b' at Umm el-Tlel (Syria), Boëda et al., 1998: 249. It is opposed to the scheme that we call with "classical" point.). The second interpretation of the method is that it consists of a convexity reinstallation starting with convergent removals which would not have been sufficiently long and which would not have crossed (if convergent removals came initially); or of a predetermined preparation allowing a debitage of convergent removals which are not necessarily supposed to cross each other (if convergent removals followed).

\section{Scheme B3}

Scheme B3 (Fig. 7) is characterized by a Levallois debitage of preferential triangular flakes with bipolar preparation and installation of lateral convexity (also included in the category of the "constructed" Levallois point production). This scheme concerns eight cores that originate from various surface sites. It is very similar to the B2 scheme because it consists of the production of a "constructed" Levallois point. In this case, the preparation is quasi-systematically bipolar, with convexity installation removals, which, like the B2 scheme, may have been produced in a predetermined way (first) or in a repair action (second).

\section{Scheme B4}

Scheme B4 (Fig. 8) is characterized by a Levallois debitage of preferential triangular flakes with proximo-lateral preparation and opposed lateral (and/or lateral) convexity installation (also included in the category of the "constructed" Levallois point production). This scheme concerns seven cores, of which two originate from the same site (RASA 2004-149-2, cores 2 and 4). It resembles the B1 scheme, but without debitage of two convergent removals. Instead there is only one proximo-lateral removal, which is the base of the predetermined operation. These are supplemented by removals of convexity reinstallation, thus completing the "construction" of the Levallois point. This scheme is rather heterogeneous in its implementation. However, it is homogeneous in its general conceptualization. 
Fig.7 An example of one core showing Scheme B3 (lithic drawing J. Espagne)
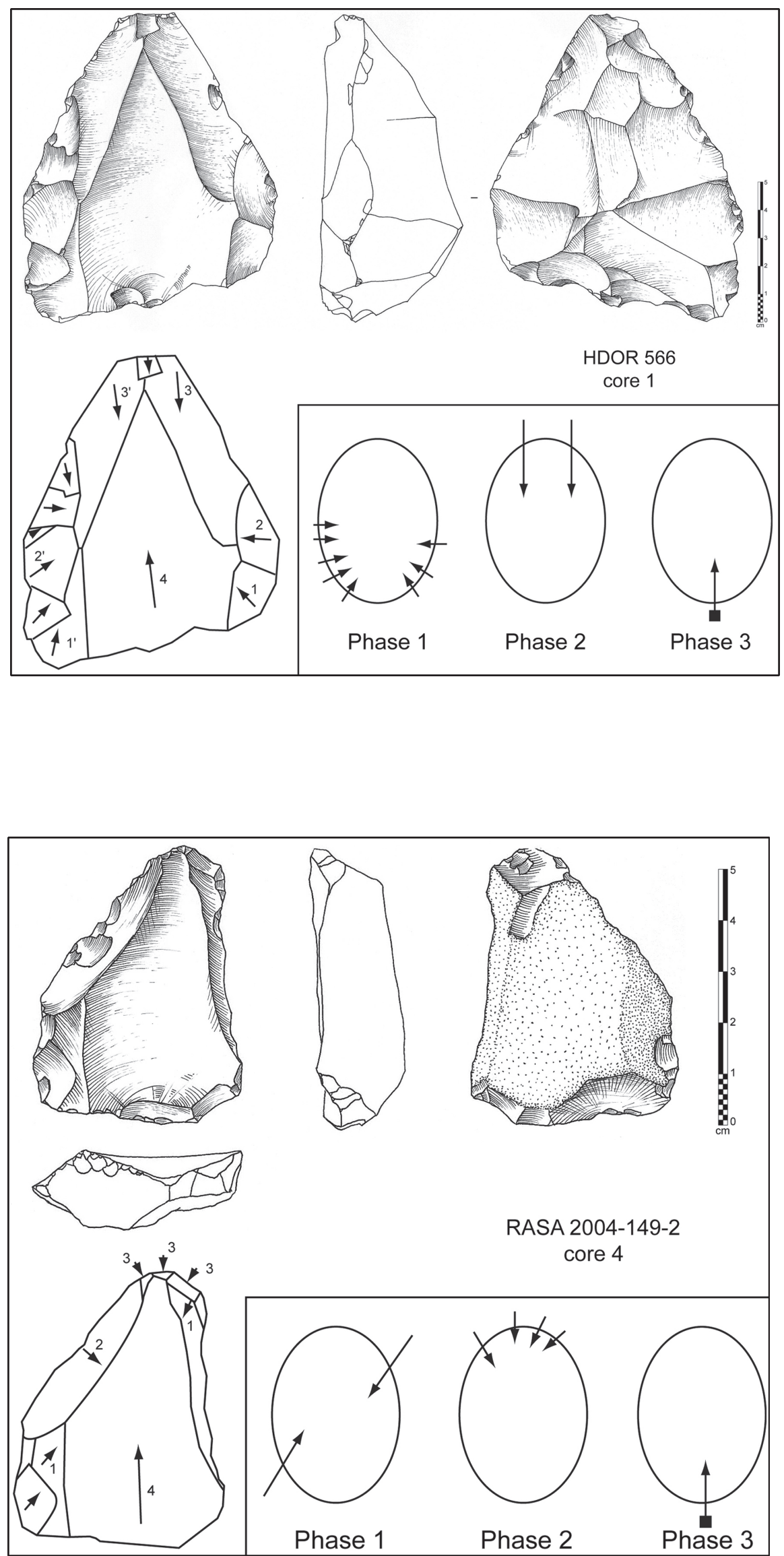

Fig. 8 An example of one core showing Scheme B4 (lithic drawing J. Espagne) 


\section{Group C}

Group C is characterized by:

A centripetal recurrent Levallois debitage (scheme C)

\section{Scheme C}

Scheme C is characterized by a centripetal recurrent Levallois debitage. No particular scheme was observed in this poorly represented group (only two cores). The relevance of this group is not clear, seeing as how it consists of a small number of cores that are severely eroded and patinated.

Four cores could not be linked to a particular group. It is probable that they are related to unfinished debitage and that they were abandoned in the process of knapping.

\section{Interim Conclusions}

The analysis of these cores demonstrates the futility of a simple typological analysis which would not have allowed us to differentiate different methods, even for the same production (of points for instance). By contrast, this study has shown that within the same Levallois method, variability can be observed.

The documentation of the variability of the methods that may result from the Levallois concept must be carried out in the rest of the Arabian peninsula. It is important, in the case of this study, to emphasize the technical schemes that are absent in our assemblages, but known elsewhere. The laminar Levallois debitage (of which core 1 from site RASA-168-1 could possibly be an example?) and the recurrent unipolar or bipolar Levallois debitage, are methods that were not identified and which do not appear to be used in Hadramawt.

\section{Comparison with Other Levallois Industries from Hadramawt and Elsewhere in Yemen}

\section{Comparison with Industries of Hadramawt from Other Archaeological Projects}

In order to extend the study of the Levallois cores from HDOR and RASA projects, some comparisons with industries from other archaeological operations in Hadramawt were carried out on the base of the available drawings in publications and according to observations of the material itself in some Yemeni museums.

In Hadramawt, taken as a geological feature, it was possible to observe lithic pieces at the museum of Say'ûn (Hadramawt region) which come from the Russian-Yemeni missions (directed by A. Sedov and H. Amirkhanov); other pieces were observed at the museum of 'Ataq (Shabwa region) which come from projects of M.-L. Inizan.

\section{The Russian-Yemeni Mission}

The Russian-Yemeni Mission to Yemen carried out a great part of its fieldwork in Hadramawt, mainly in the Wâdî Daw'an region surrounding the site of Raybûn. The prehistoric sites were discovered by Amirkhanov (Amirkhanov, 1991, 1994a, b, 1996a, b, 1997, 2006). A study of the lithics at the museum of Say'ûn that were collected by Amirkhanov, established that very few pieces had been collected. In addition all of the pieces have a strong patina which, as previously mentioned, makes the technological reading very difficult. A total of 190 of the 857 studied pieces turned out to be un-knapped natural stones. Eighteen Levallois cores from fourteen different sites were identified. Five fragments of Levallois flakes were also identified. The dominating technical scheme (10 out of 18 ) is one that aims to acquire unique preferential flakes through centripetal preparation (scheme A1). The Levallois point cores also represent a significant part (8 out of 18) of the Levallois production with prevalence of "classical" points (B1) or of "constructed" points (B2) schemes. The B3 and B4 schemes were not encountered in the study collection. Three other cores appear to have been recurrent centripetal Levallois debitage cores (diagram C) but their state of conservation is too poor to confirm their exact nature.

\section{Sites from Shabwa Region}

The majority of the prehistoric sites in the Shabwa region (Hayd Al-Ghalib, Wâdî Muqah) of Yemen were discovered by Inizan and Ortlieb. Certain Levallois pieces were sketched and published (Inizan and Ortlieb, 1985, 1987; Inizan, 1989). Their analysis had already differentiated certain technical schemes. Three schemes have already been identified by these pioneers of prehistoric Yemeni archaeology, namely the Levallois debitage of unique preferential flake with centripetal preparation, unipolar recurrent Levallois debitage of triangular flakes, and bipolar recurrent debitage of Levallois point and debordant flakes.

Some of these pieces were recently studied by the author at the Museum of 'Ataq. The previously described schemes correspond to those published by Inizan and consist of a search for preferential flakes using centripetal preparation (A1 scheme) or a search for "classical" Levallois points (B1 scheme). The presence of Levallois "constructed" point cores (schemes B2 to B4) is also attested. The recurrent debitage of flakes is also represented, but the low number of cores 
stored in the museum of 'Ataq cannot be viewed as representative of this scheme. Viewed in relation to the number of HDOR and RASA cores studied, which enabled us to have enough of a representative sample to be able to determine the dominant schemes used, the Shabwa collection is too small for such determinations.

\section{Conclusions: Levallois Debitage in Hadramawt}

It is rather clear that the technical schemes from groups $\mathrm{A}$ and B were employed throughout the Hadramawt region. The few Levallois pieces from other sites that were accessible for study and comparison with the HDOR and RASA assemblages indicated that there was in fact a relative homogeneity in the Hadramawt region.

The principal characteristics of this Levallois debitage in Hadramawt can be summarized by (Fig. 9): (1) the production of unique preferential Levallois flakes: recurrent debitage appears absent from observed pieces. The presence of workshops in proximity to the raw material can explain this phenomenon; (2) the prevalence of modalities that aim for
GROUP 1
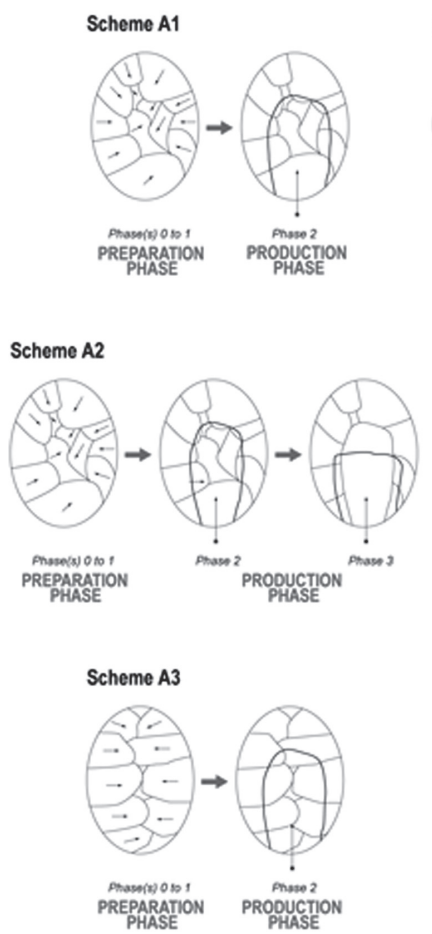

GROUP 2

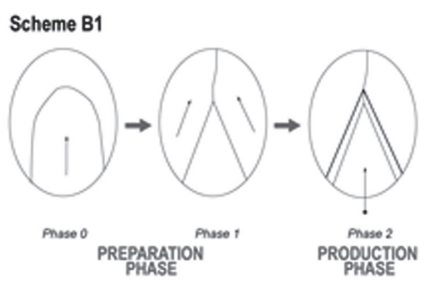

Scheme B2

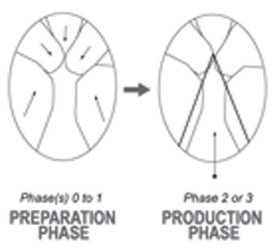

Scheme B3

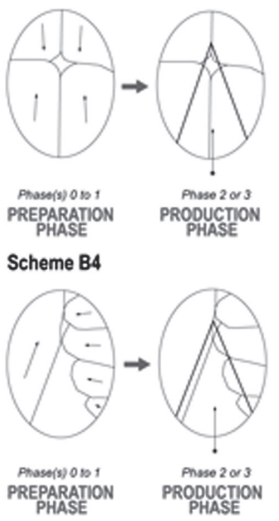

Fig.9 Synthesis of the Levallois debitage schemes from Hadramawt triangular flakes, if they are "classical" Levallois points or the so-called "constructed" points; and (3) a complexity in the knappers' technical behavior, especially in the production of the "constructed" points, when there are convex installations or reinstallation removals at various stages of the debitage.

\section{What Are the Variable Methods of Levallois Debitage in Yemen?}

According to Petraglia and Alsharekh (2003: 677), researchers working in Arabia have often noted that Levallois technology is not as well represented as in the Levantine Mousterian industries. The situation now appears quite different in Yemen. It is a lack of research that is at the origin of poor representation of Levallois technology in Yemen and not its absence or rarity in the archaeological record.

Very few Middle Paleolithic sites have been recorded in Yemen (save in Hadramawt). Until recently, Hadramawt industries were the only ones in South Arabia (even, in the Arabian peninsula) to have been analyzed technically. Nonetheless, the use of the Levallois concept has been documented in many regions in Yemen, including:

1. Aden region (Whalen and Pease, 1992; Whalen and Schatte, 1997): Wâdî Shahar and Wâdî Ghadin. It is worth noting that there is a presence of recurrent centripetal Levallois debitage of flakes in the Aden region (Whalen and Schatte, 1997, from Fig. 3: 3, 6, and 9. The three drawn cores are originally interpreted respectively as "polyhedron", "discoid" and "discoid").

2. Sâfer region (desert of Ramlat as-Sab'atayn): Wâdî Hirâb (Cleuziou et al., 1992: 9. Sites: HRB 7, HRB 20, HRB 21, HRB 25, HRB 26, HRB 27, HRB 30, HRB 31, HRB 33) and Wâdî Sadbâ (Cleuziou et al., 1992: 9. Sites: SDB 2, SDB 6).

3. Shabwa region: Khushm Tuhayfa in Wâdî Thib, Wâdî Muqqah and Hayd al'Ghalib (Inizan and Ortlieb, 1987; Inizan, 1989).

4. Western Hadramawt region: Wâdî Jirdân (YLNG-012 site; Crassard and Hitgen, 2006).

5. Say'ûn region (central Hadramawt): Wâdî al-Gabr (site al-Gabr 1) and Wâdî Hadjar (Amirkhanov, 1994a: 218); Wâdî bin 'Alî (Zimmerman, 2000).

6. Eastern Hadramawt region: Wâdî Wa'shah and Wâdî alKhûn (Crassard and Bodu, 2004) region; Wâdî Sanâ and Wâdî Shumiliya (Crassard, 2004).

7. Khamis bani Saad region (Tihâma): Shi'bat Dihya sites (Macchiarelli and Peigné, 2007), including stratified site SD-1.

However, the absence of detailed technical studies for the greater majority of the discovered pieces does not allow us to establish comparisons with those of Hadramawt. 


\section{Discussion: Repercussion of the Results from Eastern Yemen}

\section{Anatomically Modern Humans' Dispersal Routes Out of Africa}

Recent paleoanthropological debates have given place to discussions about the geographical origin of anatomically modern humans (AMH), and about human dispersal on Earth (e.g., Aiello, 1993; Klein, 1998; Stringer, 2000, 2002, 2003; Bräuer et al., 2004; Macaulay et al., 2005). One theory in particular considers that the ancestors of AMH originate from Africa alone, and appear between 200 and $100 \mathrm{ka}$ (Cann et al., 1987; Stringer and McKie, 1996; White et al., 2003; McDougall et al., 2005). This theoretical model is commonly called the "Single Origin Model". It is based on the hypothesis that Homo sapiens initially appeared in a restricted zone of Africa, about $200 \mathrm{ka}$, and dispersed toward other areas of the globe, first in the Levant around $100 \mathrm{ka}$ and after to Eurasia between 70 and $50 \mathrm{ka}$. Homo sapiens then gradually replaced ancestral species. For the supporters of this theory, the area where the first AMH would have first speciated would be in East or South Africa.

Although the paleontological, archaeological and genetic evidence is increasingly converging, and suggests an African origin for $\mathrm{AMH}$, there is still disagreement regarding human dispersal routes out of the African continent. Different models of diffusion have been proposed (Kingdon, 1993; Lahr and Foley, 1998; Van Peer, 1998; Hublin, 2000; Stringer, 2000; Bar-Yosef and Belfer-Cohen, 2001; Ambrose, 2003). Nevertheless, such models remain hypothetical as there is little archaeological data to support them.

One of the proposed dispersal routes runs from Eastern Africa to the Levant, running along the Nile valley and crossing over through the Sinai (Tchernov, 1992; Bar-Yosef and Belfer-Cohen, 2001). This hypothesis holds ground as it has been substantiated by data showing a clear resemblance between Middle Paleolithic assemblages from the Nile region and from the Levant (McBurney, 1975; Clark, 1989; Van Peer, 1998).

A second human dispersal route has gained popularity in recent years. It has been proposed that humans crossed from Africa to Arabia via the strait of Bab al Mandab. This dispersal route is often referred to as the "Southern Dispersal Route" (Brandt, 1986; Nayeem, 1990; Kingdon, 1993; Lahr and Foley, 1994, 1998; Walter et al., 2000; Mithen and Reed, 2002; Ambrose, 2003; Petraglia, 2003; Rose, 2004a, b; Derricourt, 2005; Field and Lahr, 2005; Forster and Matsumura, 2005; James and Petraglia, 2005; Macaulay et al., 2005; Beyin, 2006) or the "Bab al Mandab connection" (Cleuziou, 2004: 126) but has never been confirmed due to a lack of archaeological evidence. The lithic industries discovered by Amirkhanov in Hadramawt, which were published without a proper description of the pieces, and using purely typological labels, are regularly evoked by proponents of this theory in comparison with African industries. In addition the lithic industries discovered by Whalen in the Southern Yemeni Highlands are also used as references for African comparisons despite the fact that their analysis remains insufficient (Whalen and Pease, 1992; Whalen and Schatte, 1997).

The Levallois debitage methods and modalities that were recognized in Hadramawt (Wâdî Wa'shah and Wâdî Sanâ) thus constitute an important corpus of reference for a comparison with lithic industries from East Africa and the Levant.

\section{What Are the Possible Comparisons with Neighboring Regions?}

Since chronological data for the Levallois assemblages from Yemen do not yet exist, it is impossible to discuss affinities with industries from elsewhere. In contrast, typo-technological comparisons are justified as a means of comparison, as long as the final exploitation stages of the cores from Hadramawt (Wâdî Wa'shah and Wâdî Sanâ) fall into clear patterns. This first level of analysis, which involves the comparison of technical schemes is carried out as a technological exercise and with the full knowledge that contemporaneity is not necessarily a factor in the comparisons that may arise. Nonetheless, this does not prevent discussions of possible human dispersals and diffusions.

We propose to make a first assessment of the resemblances and differences that were observed between Middle Paleolithic assemblages from East Africa and the Levant, and the Levallois debitage characteristics from Hadramawt. The comparisons will be centered on the production modalities of Levallois points, which are more distinctive (than the "traditional" modalities of Levallois debitage of flakes) and whose characteristics indicate different debitage conceptions. This first comparative study, which is based on material from Yemen that was studied with technological accuracy, is nevertheless preliminary and will be developed in future studies.

\section{Some Comparisons with Northeastern Africa and the "Nubian Mousterian"}

In Northeast Africa, and especially in Nubia and the Nile Valley, several Levallois debitage methods have been recognized. Two principal methods were identified within the Nubian Levallois assemblages and from other areas in Northeast Africa (Guichard and Guichard, 1965; Vermeersch 
et al., 1990; Van Peer, 1991, 1992, 1998; Wurz et al., 2005), i.e., the "Nubian Method Type 1" and the "Nubian Method Type 2".

The Nubian Method Type 1 (Fig. 10) is well known from the Egyptian and Sudanese (especially the Lower Nile Valley) Paleolithic assemblages (Guichard and Guichard, 1965: 68-69; Van Peer, 1992: 40-41, Fig. 21/2). This technical scheme develops in this way:

1. Phase 1: Preliminary shaping of a narrow and oval core.

2. Phase 2: Removal of two long flakes from the pointed distal part of the core, with close bulb negatives. These removals create a central arris in the axis of symmetry of the core which will be used as a guiding arris for the predetermined removal.

3. Phase 3: Preparation retouches of the proximal part of the core (striking platform).

4. Phase 4: Removal of a Levallois point (predetermined triangular flake), from the proximal part of the core, which follows the central guiding arris.

This Nubian Method Type 1 is scarcely present in Hadramawt. It resembles what was observed on some cores of the bipolar preparation scheme B3, for example core HDOR 566-1 (Crassard, 2007: vol. 2, p. 7) and, more convincingly, core HDOR 571-1 (Crassard, 2007: vol. 2, p. 8).

The Nubian Method Type 2 (Fig. 10) is a Levallois debitage method that was also recognized in the Lower Nile Valley (Northern Sudan and Southern Egypt; Guichard and Guichard, 1965: 69; Van Peer, 1992: 41, Fig. 21/1). The shaping of the core resembles the preparation involved in the Nubian Method 1. The characteristic preparation of the Nubian method 2 takes place with the removal of flakes from lateral and distal segments of the core. This method can resemble a modality seeking the production of non-triangular preferential flakes. However, the preparation regularly creates a central guiding arris in the longitudinal symmetry axis of the core. The obtainment of a point is thus the final objective of this type of debitage.

The Nubian Method Type 2 is closely associated to a modality of debitage seeking "constructed points", found particularly in the scheme B2 and maybe B4 from Hadramawt.
In Nubia, the presence of "classical" Levallois point cores is mentioned (non Nubian methods; Guichard and Guichard, 1965: 85-86) and suggests a resemblance with the B1 scheme ("classical" points) described in Hadramawt. The preferential flake cores are also mentioned, and are comparable to the Hadramawt C group.

A "Nubian Mousterian" cultural group was proposed and was divided into the rather well-defined groups $\mathrm{N}$ and $\mathrm{K}$ (Van Peer, 1991: 111). These groups are differentiated on the basis of the Levallois methods involved in each. In the group $\mathrm{N}$ assemblages, the Nubian methods and the Levallois "classical" debitage of preferential flakes, are associated. Contrarily to this, the group $\mathrm{K}$ assemblages are not made using the Nubian method. The tools associated with these groups are very rare in Nubia.

There are similar components in Hadramawt that sometimes include the joint presence of schemes from groups $\mathrm{A}$ or $\mathrm{B}$ with that of scheme $\mathrm{C}$ and which correspond to the description of the Nubian Mousterian N group.

\section{Some Comparisons with the Near-East and the Levantine Mousterian}

Levallois modalities were studied on many mostly stratified sites in the Levant. They are associated with the Middle Paleolithic ("Levantine Mousterian"; Jelinek, 1982; Marks, 1992).

Close to Mount Carmel in Israel, the site of Kebara delivered an important corpus of Levallois material dating to between 60 and $48 \mathrm{ka}$. This assemblage was used to understand the technical variability of the Mousterian industries and the technical behavior of the Neanderthals in the NearEast (Meignen and Bar-Yosef, 1990). At the site of Kebara the Levallois debitage is present in all of the archaeological levels and the production of points, using predetermined convergent unipolar removals, dominates the assemblages. The obtained preferential products are especially short points with wide bases. This type of debitage in particular, presents a lesser degree of preparation of the debitage and dorsal
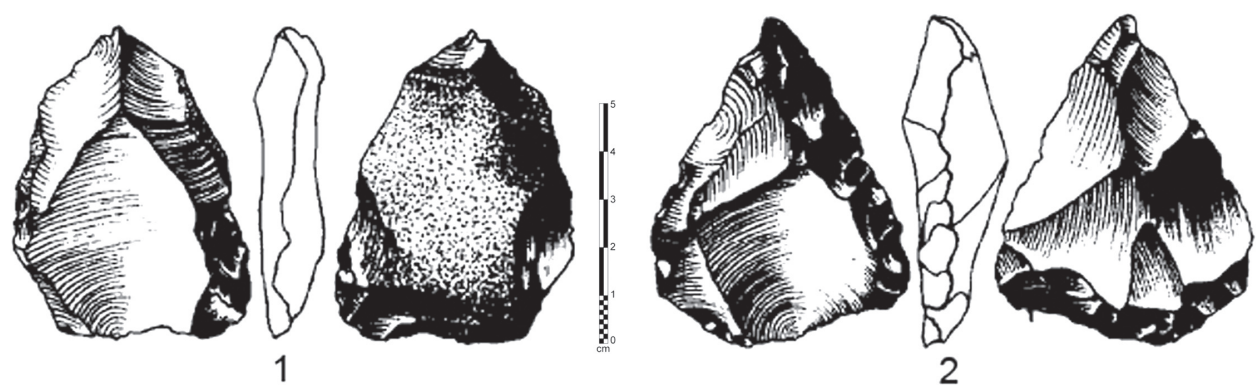

Fig. 10 Two cores showing the Nubian Method 1 (left) and 2 (right), after Van Peer (1992: Fig. 21/2) 
surfaces, which indicates good control of the knapping operations.

These dominant characteristics are found on other sites in the Levant. In Tabun (Copeland, 1975; Jelinek, 1981), about fifteen kilometers North of Kebara, the convergent unipolar preparation modality is similar in layers B and D, with an even larger proportion of points than at Kebara. The presence of Levallois debitage of flakes with centripetal preparation in contemporary layers where Levallois debitage also aims towards the production of points, does not allow us to demonstrate the presence of a linear evolution for Mousterian industries. Given this, it becomes impossible to use the study of lithic industries as a dating criterion.

This modality of convergent unipolar production of Levallois points appears to be a characteristic element of the Near-East in certain periods (Meignen, 1995), but which remains less present in Northeast Africa. Crew (1975) highlighted a dominance of preparation/exploitation operations from the proximal zone of the cores in the Levant, which was clearly distinguished from the more diversified preparation/ exploitation schemes in Northeast Africa (mainly Libya). Among these African schemes, removals coming from the lateral segments were more frequent.

This Levantine production of "classical" points is very similar to the B1 scheme identified in Hadramawt.

The convergent unipolar Levallois modality is also found in some layers of the Paleolithic site of Umm el-Tlel, in Syria, and in particular in the Mousterian layer VI3 b', dated to 65-50 ka (Boëda and Muhesen, 1993: 55-56, Figs. 19-20). At Umm el-Tlel, this scheme is called 'scheme $A$ ' and belongs to the set of points "à trois coups" ("with three hits"). 'Scheme B' (orthogonal preparation) and 'F' (on the ventral face of a flake) are also found in the same archaeological level at this site.

Other modalities from level 'VI3 b' at Umm el-Tlel consist of the production of "constructed" points (Fig. 11; Boëda et al., 1998: 249-250, Fig. 9). 'Scheme C' from this site (with lateral preparation) resembles scheme B2 from Hadramawt though it is not strictly identical. Scheme B2 from Hadramawt is based on preliminary convergent unipolar removals. Lateral removals are a later addition and are meant to reinstall convexities and the central guiding arris.

'Scheme E' from Umm el-Tlel (with bipolar preparation) also resembles the debitage concept of schemes B2 and B3 from Hadramawt. Once again, the Hadramawt schemes differ slightly from those proposed by Boëda, but are part of the same knapping concept which seeks the production of points.

Finally, 'scheme B' from Umm el-Tlel (with orthogonal preparation) can be compared to scheme B4 ("constructed points") from Hadramawt. The first ('B') presents a preparation "à trois coups", whereas the second (B4) is less strict: several removals are made from the lateral part rather than only one. To conclude, no example of the schemes D and F from Umm el-Tlel were recognized in Hadramawt.

Besides the Levallois debitage of "classical" points, not a single Umm el-Tlel scheme perfectly matches those of the assemblages from Hadramawt. Nevertheless, it is possible to highlight resemblances between the various debitage modalities of "constructed" points. These resemblances provide a common objective (point production), achieved by "alternative" modalities, in comparison to the strict modality of convergent unipolar preparation. These types of modalities also exist elsewhere in the Near-East, particularly in Kebara, but are not dominant (L. Meignen, pers. comm., 2006).

\section{Conclusions}

The techniques from the Arabian Middle Paleolithic remain largely unknown and mostly ignored by scholars. Nevertheless, it would seem, thanks to the studies of Hadramawt's Levallois industries, that there are technical similarities with some Mousterian industries from the Levant. Also, from our first comparisons, no conclusive archaeological affinities between East Africa and Arabia sustain the Southern dispersal route model. Whether these resemblances with the Levant material are evidences of a specific link, and during which period(s), remains unknown. Where do the original

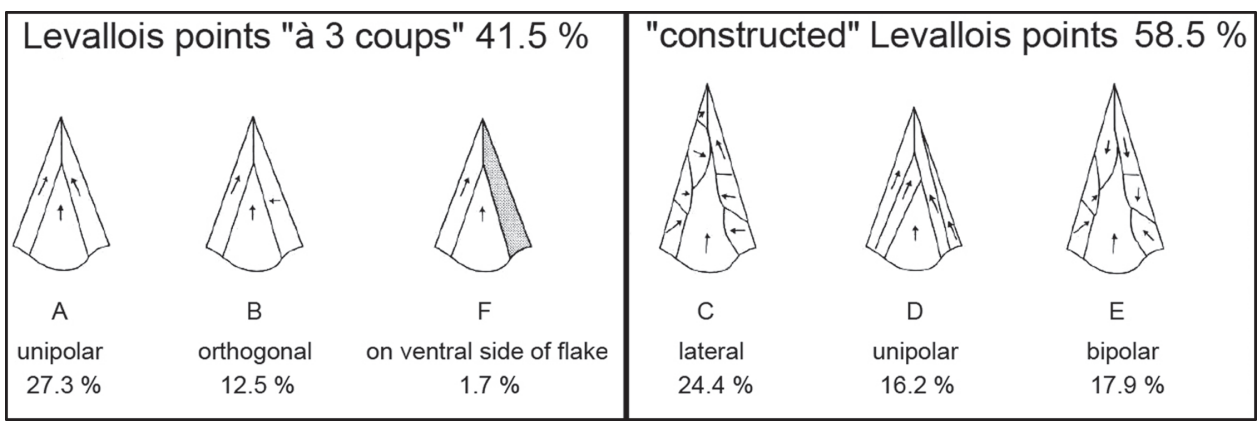

Fig. 11 Alternate flaking processes for the production of Levallois points from Umm el-Tlel, after Boëda et al. (1998: Fig. 9) 
technical traditions come from? Did the Levant have a primary influence on Arabia, or is the contrary possible? These questions emphasize the enormous potential represented by South Arabia, in the still young studies concerning the peopling of Asia and the hominin expansion out of Africa.

Until now, no conclusion can be definitively proposed, as no Levallois site has been chronometrically dated in South Arabia (see Marks, 2009). Nevertheless, the existence of technological affinities is undeniable with some neighboring areas of Hadramawt where Levallois assemblages are found. It appears anyway that resemblances are more convincing with the Levant, considering the "constructed" debitage conception or the knapper's qualitative choices. If the chronological data could confirm a dating to ca. $50 \mathrm{ka}$ for the Levallois industries from South Arabia, it would be then necessary to reconsider with attention the role of this area in the occupation and peopling modalities by Middle Paleolithic human groups. Relations, whose character remains to be defined, with the Levantine Mousterian would be then more probable than with an African Middle Stone Age (MSA) or Nubian Mousterian.

The variability of the Levallois debitage modalities we observe in South Arabia could then be explained by local evolution during the Upper Pleistocene, due to a possible situation of cultural isolation. A population, locally embedded, could have developed specific technological habits in the region. This is, for instance, something that happened in the Levantine Middle Paleolithic and in the Late MSA of Eastern Africa during the Oxygen Isotope Stages 5 and 4. A similar situation is largely attested during the Early/Mid-Holocene period (seventh to fifth million BC) in Yemen, like the existence of innovative and unique technical systems in the Old World such as fluting (Crassard et al., 2006; Crassard, 2007). This hypothesis of some regional locally emerged specificities developed as early as the Middle Paleolithic fits quite well with our preliminary analysis and the neighboring data. Later on, Southern Arabia seems to have been in a cultural isolation as suggested by a nearly absence of Upper Paleolithic phenomenon, correlated with a possible Middle Paleolithiclike complex until the first Holocene industries. Before us, Whalen (Whalen et al., 1981) had proposed to see in the South Arabian Paleolithic assemblages an endemic technological development, incorporating some technical and stylistic traditions which would have allowed optimizing human adaptation to the environmental conditions.

Furthermore, the absence of an Upper Paleolithic in Arabia is an additional problem to the regional prehistory definition. This period is quite simply unknown; perhaps even non-existent in Yemen's chronology and in its closest regions. The Upper Paleolithic problem, even if some insights seem to have been discovered in Eastern Yemen (Amirkhanov, 2006), is particularly important when one can see a possible technical continuity of the Levallois debitage all along the
Upper Pleistocene, until the "explosion" of the sophisticated industries during Early/Mid-Holocene (Crassard et al., 2006; Crassard, 2008), which means the absence of a clear long technical transition, the absence thus of an Upper Paleolithic. This remains to be proven, and it is another story.

Acknowledgments I gratefully acknowledge the assistance provided by Dr Abdullah Bawazir, President of the General Organization for Antiquities and Museums of the Republic of Yemen and his able staff, particularly Abdul Rahman Assaqaf, Hussein Alaydarus and Khairan Alzubaidi. I thank the RASA Projects directors: Joy McCorriston, Erich Oches and Abdulaziz bin Aqil, and the French Archaeological Mission in Jawf-Hadramawt directors: Michel Mouton, Frank Braemer, and Anne Benoist. For their comments on previous drafts and general discussion about South Arabian Prehistory, I gratefully acknowledge the help of Hizri Amirkhanov, Pierre Bodu, Anne Delagnes, MarieLouise Inizan, Jacques Jaubert, Roberto Macchiarelli, Liliane Meignen, Jeffrey Rose and especially Michael Petraglia. I owe special thanks to Lamya Khalidi and Michael Haslam for comments on a draft of this chapter. I thank the Fondation Fyssen for providing financial support for my stay in Cambridge, and I thank the LCHES staff for their warm hospitality.

\section{References}

Aiello LC. The fossil evidence for modern human origins in Africa: a revised view. American Anthropologist. 1993;95:73-96.

Ambrose S. Population bottleneck. In: Robinson R, editor. Genetics. Farmington Hills: Macmillan References; 2003. p. 167-71.

Amirkhanov HA. Palaeolithic in South Arabia. Moscow (in Russian): Scientific World; 1991.

Amirkhanov HA. Research on the Palaeolithic and Neolithic of Hadramaut and Mahra. Arabian Archaeology and Epigraphy. 1994a;5:217-28.

Amirkhanov HA. Recherches sur le néolithique dans le Hadramaout en 1991. Chroniques Yéménites. 1994b;1994:54-5.

Amirkhanov HA. Notes on the stone tools from Raybun I settlement. In: Sedov A, Griaznevich P, editors. Raybun settlement (1983-1987 excavations). Moscow: Vostochnaya Litteratura; 1996a. p. 31-4.

Amirkhanov HA. Bilinear parallelism in the Arabian Early Neolithic. In: Afanasev G, Cleuziou S, Lukacs R, Tosi M, editors. The prehistory of Asia and Oceania, XIIIth International Congress of Prehistoric and Protohistoric Sciences. Abaco, Forli: Forli; 1996b. p. 135-9.

Amirkhanov HA. The Neolithic and PostNeolithic of the Hadramaut and Mahra. Moscow (in Russian): Scientific World; 1997.

Amirkhanov HA. Stone Age of South Arabia. Moscow (in Russian): Nauka; 2006.

Bar-Yosef O, Belfer-Cohen A. From Africa to Eurasia-early dispersals. Quaternary International. 2001;75:19-28.

Beyin A. The Bab al Mandab vs. the Nile-Levant: an appraisal of the two dispersal routes for early modern humans out of Africa. African Archaeological Review. 2006;23:5-30.

Boëda E. Le concept Levallois: variabilité des méthodes, Monographie du CRA 9. Paris: CNRS Editions; 1994.

Boëda E, Muhesen S. Umm el Tlel (El Kowm, Syrie): étude préliminaire des industries lithiques du Paléolithique moyen et supérieur 1991-1992. Cahiers de l'Euphrate (Editions Recherche sur les Civilisations, Paris). 1993;7:47-89.

Boëda E, Bourguignon L, Griggo C. Activités de subsistance au Paléolithique moyen: couche VI3 b' du gisement d'Umm El Tlel (Syrie). In: Brugal JP, Meignen L, Patou-Mathis M, editors. Economie 
Préhistorique: Les Stratégies de Subsistance au Paléolithique. SophiaAntipolis: XVIII Rencontres Internationales d'Histoire et d'Archéologie d'Antibes, Editions APDCA; 1998.

Brandt SA. The Upper Pleistocene and Early Holocene prehistory of the Horn of Africa. African Archaeological Review. 1986;4:41-82.

Bräuer G, Collard M, Stringer C. On the reliability of recent tests of the Out of Africa hypothesis for modern human origins. Anatomical Record. 2004;279A:701-7.

Burns SJ, Fleitmann D, Matter A, Kramers J, Al-Subbary A. Indian ocean climate and an absolute chronology over Dansgaard/Oeschger events 9 to 13 . Science. 2003;301:1365-7.

Cann RL, Stoneking M, Wilson AC. Mitochondrial DNA and human evolution. Nature. 1987;325:31-6.

Caton-Thompson G. Geology and archaeology of the Hadramaut, Southern Arabia. Nature. 1938;142:139-42.

Caton-Thompson G. Some Palaeoliths from South Arabia. Proceedings of the Prehistoric Society. 1953;19:189-218.

Clark JD. The origin and spread of modern humans: a broad perspective on the African evidence. In: Mellars PA, Stringer C, editors. The human revolution: behavioural and biological perspectives on the origins of modern humans. Edinburgh: Edinburgh University Press; 1989. p. 565-88.

Cleuziou S. Pourquoi si tard? Nous avons pris un autre chemin. L'Arabie des chasseurs-cueilleurs de l'Holocène au début de l'Age du Bronze. In: Guilaine J, editor. Aux Marges des Grands Foyers du Néolithique, Périphéries Débitrices ou Créatrices? Paris: Errance Editions; 2004. p. $123-48$.

Cleuziou S, Inizan M-L, Marcolongo B. Le peuplement pré- et protohistorique du système fluviatile fossile du Jawf-Hadramawt au Yémen (d'après l'interprétation d'images satellite, de photographies aériennes et de prospections). Paléorient. 1992;18(2):5-28.

Copeland L. The Middle and Upper Palaeolithic of Lebanon and Syria in the light of recent research. In: Wendorf F, Marks A, editors. Problems in prehistory: North Africa and the Levant. Dallas: SMU Press; 1975. p. 317-50.

Crassard R. Prehistory in Wadi Sana: the lithic industries, Roots of Agriculture in South Arabia Preliminary Report 2004, Unpublished preliminary report; 2004.

Crassard R. Apport de la technologie lithique à la définition de la préhistoire du Hadramawt, dans le contexte du Yémen et de l'Arabie du Sud. Ph.D. dissertation, Université Paris 1, Panthéon-Sorbonne; 2007.

Crassard R, Bodu P. Préhistoire du Hadramawt (Yémen): nouvelles perspectives. Proceedings of the Seminar for Arabian Studies. 2004;34:67-84.

Crassard R, Hitgen H. Final report: "Bronze Age Tombs" Project (YLNG-BAT 2006); Archaeological excavations. Unpublished internal report Yemen LNG, CEFAS/DAI, Sana'a (English and Arabic versions); 2006.

Crassard R, McCorriston J, Oches E, bin Aqil A, Espagne J, Sinnah M. Manayzah, early to mid-Holocene occupations in Wâdî Sanâ. Proceedings of the Seminar for Arabian Studies. 2006;36:151-73.

Crew $\mathrm{H}$. An examination of the vatiability of the Levallois methods: its implication for the internal and external relationships of the Levantine Mousterian. Ph.D. dissertation, University of Columbia, Columbia; 1975.

Derricourt R. Getting "Out of Africa": sea crossings, land crossings and culture in the hominin migrations. Journal of World Prehistory. 2005; 19:119-32.

Field JS, Lahr MM. Assessment of the southern dispersal: GIS-based analyses of potential routes at oxygen isotopic stage 4. Journal of World Prehistory. 2005;19:1-45.

Forster P, Matsumura S. Did early humans go north or south? Science. 2005;308:965-6.

Guichard J, Guichard G. The Early and Middle Palaeolithic of Nubia: a preliminary report. In: Wendorf F, editor. Contributions to the prehistory of Nubia. Dallas: SMU Press; 1965. p. 57-116.
Hublin J-J. Modern-nonmodern hominid interactions: a Mediterranean perspective. In: Bar-Yosef O, Pilbeam D, editors. The geography of Neanderthals and modern humans in Europe and the Greater Mediterranean, Bulletin 8. Cambridge, MA: Peabody Museum of Archaeology and Ethnology; 2000. p. 157-82.

Inizan M-L. Premiers éléments de Préhistoire dans la région de Shabwa (R.D.P. du Yémen). Raydan. 1989;5:71-7.

Inizan M-L, Ortlieb L. Yémen, R.C.P. 743, Préhistoire au MoyenOrient, évolution des industries dans leur contexte paléo-écologique. Unpublished CNRS Activity Report; 1985. p. 9-21.

Inizan M-L, Ortlieb L. Préhistoire dans la region de Shabwa au Yémen du sud (R. D. P. Yémen). Paléorient 1987;13(1):5-22.

James HVA, Petraglia M. Modern human origins and the evolution of behavior in the Later Pleistocene record of South Asia. Current Anthropology. 2005;46(suppl):3-27.

Jelinek AJ. The Middle Palaeolithic in the Southern Levant from the perspective of the Tabun cave. In: Cauvin J, Sanlaville P, editors. Préhistoire du Levant. Paris: CNRS; 1981. p. 265-80.

Jelinek AJ. The Tabun Cave and Palaeolithic Man in the Levant. Science. 1982;216:1369-75.

Keita L. The "Africa and the rest of the world evolutionary hypotheses": an exercise in scientific epistemology. African Archaeological Review. 2004;21(1):1-6.

Kingdon J. Self-made man: human evolution from Eden to extinction. New York: Wiley; 1993.

Klein RG. Why anatomically modern people did not disperse from Africa 100,000 years ago. In: Akazawa T, Aoki K, Bar-Yosef O, editors. Neanderthals and modern humans in Western Asia. New York: Plenum; 1998. p. 509-21.

Lahr MM, Foley R. Multiple dispersals and modern human origins. Evolutionary Anthropology. 1994;3:48-60.

Lahr MM, Foley R. Towards a theory of modern human origins: geography, demography, and diversity in recent human evolution. Yearbook of Physical Anthropology. 1998;41:137-76.

Macaulay V, Hill C, Achilli A, Rengo C, Clarke D, Meehan W, et al. Single, rapid coastal settlement of Asia revealed by analysis of complete mitochondrial genomes. Science. 2005;308:1034-6.

Macchiarelli R, Peigné S. Le premier peuplement humain de l'Arabie méridionale: la perspective Tihama (Yémen). Bulletins et Mémoires de la Société d'Anthropologie de Paris, n.s. 2007;18:15-6.

Marks A. Upper Pleistocene archaeology and the origins of modern man: a view from the Levant and adjacent areas. In: Akazawa T, Aoki K, Kimura T, editors. The evolution and dispersal of modern humans in Asia. Tokyo: Hokusen-Sha; 1992. p. 229-51.

Marks AE. The Paleolithic of Arabia in an inter-regional context. In: Petraglia MD, Rose JI, editors. The evolution of human populations in Arabia: paleoenvironments, prehistory and genetics. The Netherlands: Springer; 2009. p. 295-308.

McBurney C. Current status of the Lower and Middle Paleolithic of the entire region from the Levant through North Africa. In: Wendorf F, Marks A, editors. Problems in prehistory: North Africa and the Levant. Dallas: SMU Press; 1975. p. 411-26.

McDougall I, Brown F, Fleagle J. Stratigraphic placement and age of modern humans from Kibish, Ethiopia. Nature. 2005;433(17): 733-6.

Meignen L. Levallois lithic production systems in the Middle Paleolithic of the Near East: the case of the unidirectional method. In: Dibble $\mathrm{H}$, Bar-Yosef $\mathrm{O}$, editors. The definition and interpretation of Levallois technology. Monographs in World Archaeology 23. Madison, WI: Prehistory Press; 1995. p. 361-79.

Meignen L, Bar-Yosef O. Kebara et le Paléolithique Moyen du Mont Carmel. Paléorient. 1990;14(2):123-30.

Mithen S, Reed M. Stepping out: a computer simulation of hominid dispersal from Africa. Journal of Human Evolution. 2002;43:433-62.

Nayeem MA. Prehistory and protohistory of the Arabian peninsula, vol.1: Saudi Arabia. Hyderabad: Hyderabad Publishers; 1990. 
Petraglia MD. The Lower Paleolithic of the Arabian peninsula: occupations, adaptations, and dispersals. Journal of World Prehistory. 2003;17(2):141-79.

Petraglia MD. Mind the gap: factoring the Arabian peninsula and the Indian subcontinent into Out of Africa models. In: Mellars P, Boyle $\mathrm{K}$, Bar-Yosef O, Stringer C, editors. Rethinking the human revolution. Cambridge: McDonald Institute Monographs; 2007. p. 383-94.

Petraglia MD, Alsharekh A. The Middle Palaeolithic of Arabia: implications for modern human origins, behaviour and dispersals. Antiquity. 2003;77:671-84.

Rose JI. The question of Upper Pleistocene connections between East Africa and South Arabia. Current Anthropology. 2004a;45(4):551-5.

Rose JI. New evidence for the expansion of an Upper Pleistocene population out of East Africa, from the site of Station One, northern Sudan. Cambridge Archaeological Journal. 2004b;14(2):205-16.

Sanlaville P. Le Moyen-Orient arabe: le milieu et l'homme. Paris: Armand Colin; 2000.

Stringer C. Coasting out of Africa. Nature. 2000;405:24-7.

Stringer C. Modern human origins: progress and prospects. Philosophical Transactions of the Royal Society London (B). 2002;357:563-79.

Stringer C. Human evolution: out of Ethiopia. Nature. 2003;423:692-5.

Stringer C, McKie R. African Exodus: the origins of modern humanity. London: Pimlico Press; 1996.

Tchernov E. Biochronology, paleoecology, and dispersal events of hominids in the southern Levant. In: Akazawa T, Aoki K, Kimura T, editors. The evolution and dispersal of modern humans in Asia. Tokyo: Hokusen-sha; 1992. p. 149-88.

Tuffreau A. L'Acheuléen de l'Homo erectus à l'Homme de Neandertal. Paris: La Maison des Roches Editeur; 2004.

Van Beek GW, Cole GH, Jamme Aluf GH. An archaeological reconnaissance in Hadramaut: a preliminary report. Annual Report of the Smithsonian Institute; 1963.
Van Peer P. Interassemblage variability and Levallois styles: the case of the northern African Middle Paleolithic. Journal of Anthropological Archaeology. 1991;10:107-51.

Van Peer P. The Levallois reduction strategy. Monographs in World Archaeology 13. Madison, WI: Prehistory Press; 1992.

Van Peer P. The Nile corridor and the Out-of-Africa model: an examination of the archaeological record. Current Anthropology. 1998:39:115-40.

Vermeersch PM, Paulissen E, Van Peer P. Le Paléolithique de la vallée du Nil égyptien. L'Anthropologie. 1990;94:435-58.

Walter RC, Buffler RT, Bruggemann JH, Guillaume MMM, Berhe SM, Negassi B, et al. Early human occupation of the Red Sea coast of Eritrea during the Last Interglacial. Nature. 2000;405:65-9.

Whalen NM, Pease DW. Archaeological survey in southwest Yemen. Paléorient. 1992;17(2):127-31.

Whalen NM, Schatte KE. Pleistocene sites in southern Yemen. Arabian Archaeology and Epigraphy. 1997;8:1-10.

Whalen NM, Killick A, James N, Morsi G, Kamal M. Saudi Arabian archaeological reconnaissance 1980 , preliminary report on the Western Province survey. Atlal. 1981;5:43-58.

White TD, Asfaw B, DeGusta D, Gilbert H, Richards G, Suwa G, et al. Pleistocene Homo sapiens from Middle Awash, Ethiopia. Nature. 2003;423:742-7.

Wurz S, van Peer P, le Roux N, Gardner S, Deacon HJ. Continental patterns in stone tools: a technological and biplot-based comparison of early Late Pleistocene assemblages from northern and southern Africa. African Archaeological Review. 2005;22(1):1-24.

Zarins J. View from the south: the Greater Arabian peninsula. In: Henry D, editor. Prehistoric archaeology of Jordan. Oxford: BAR International Series 705; 1998. p. 179-94.

Zimmerman P. Middle Hadramawt archaeological survey: preliminary results, October 1999 season. Yemen Update. 2000;42:27-9. 